\title{
Potential use of smartly engineered red mud nanoparticles for removal of arsenate and pathogens from drinking water
}

\author{
Joy Sankar Roy ${ }^{1,5}$. Gourav Bhattacharya ${ }^{1,2}$. Deepika Chauhan ${ }^{3}$. Sujit Deshmukh ${ }^{1}$. Ravikant Upadhyay ${ }^{4}$ \\ Richa Priyadarshini ${ }^{3} \cdot$ Susanta Sinha Roy ${ }^{1}$ (])
}

Received: 20 December 2019 / Accepted: 24 March 2020 / Published online: 2 April 2020

(c) Springer Nature Switzerland AG 2020

\begin{abstract}
The aluminum industrial waste red mud was successfully utilized as a novel adsorbent for the removal of arsenic (As) ions from water. The arsenate (As (V)) adsorption efficacy of red mud nanoparticles was also investigated. Red mud nanoparticles were prepared by ball milling raw red mud for $10 \mathrm{~h}$, yielding particles' size of $20 \mathrm{~nm}$ on average. The As (V) adsorption on these nanoparticles strongly depended on the size of the nanoparticles. As (V) removal increased from 58 to $83 \%$ by reducing the size of red mud particles from 200 to $20 \mathrm{~nm}$. Detail kinetics and transport study confirmed the pseudo-second-order kinetic process which was governed by external mass transport. The Freundlich (and Langmuir) isotherms confirm that the arsenate adsorption capacity changes from $2.28 \mathrm{mg} / \mathrm{g}(1.84 \mathrm{mg} / \mathrm{g})$ to $2.54 \mathrm{mg} / \mathrm{g}(1.96 \mathrm{mg} / \mathrm{g})$ for reduction of particles from size $200 \mathrm{~nm}$ to $20 \mathrm{~nm}$. Water filter columns made with red mud nanoparticles prepared by ball milling for $10 \mathrm{~h}$ showed better filtration performance than the filter packed with raw red mud. Both the hydraulic conductivity and the As $(\mathrm{V})$ removal $(8 \mathrm{~mm} / \mathrm{h}$ and $61 \%$ respectively) of influent $1 \mathrm{mg} / \mathrm{L} \mathrm{As}(\mathrm{V})$ by red mud nanoparticles were greater than the raw red mud $(3.2 \mathrm{~mm} / \mathrm{h}$ and $54 \%)$. The modified red mud column filters also exhibited a higher efficiency than the raw red mud filters to remove Escherichia coli and Staphylococcus aureus from the water. Overall, this research shows that nanomaterials derived from aluminum processing waste can be a promising material for water filtration.
\end{abstract}

Keywords Red mud nanoparticles · Arsenate adsorption $\cdot$ E. coli removal $\cdot$ S. aureus removal $\cdot$ Water filtration

\section{Introduction}

Arsenic is a widespread toxic pollutant, which has been found in the groundwater of many countries [1-4]. Its presence can be attributed to both natural and anthropogenic sources. Although environmental regulations have limited the production and use of arsenic and its compounds, these are still extensively used in metallurgy, agriculture, forestry, electronics, pharmaceuticals, glass, and ceramic industry. Arsenic in natural water exists only in the form of arsenate or As (V) and arsenite or As (III) [4]. The consumption of arsenic-contaminated water causes several toxic and carcinogenic effects on human beings. It has been reported that the long-term uptake of arsenic-contaminated drinking water results in the gastrointestinal, skin, liver and nerve tissue damages $[5,6]$. The toxicity of arsenic

Joy Sankar Roy and Gourav Bhattacharya have contributed equally to this work.

$\triangle$ Susanta Sinha Roy, susanta.roy@snu.edu.in | 'Department of Physics, Shiv Nadar University, NH-91, Tehsil Dadri, G. B. Nagar, Uttar Pradesh 201314, India. ${ }^{2}$ Nanotechnology and Integrated Bioengineering Centre, University of Ulster, Jordanstown Campus, Newtownabbey BT37 OQB, Northern Ireland, UK. ${ }^{3}$ Department of Life Science, Shiv Nadar University, NH-91, Tehsil Dadri, G. B. Nagar, Uttar Pradesh 201314, India. ${ }^{4}$ Department of Chemistry, Shiv Nadar University, NH-91, Tehsil Dadri, G. B. Nagar, Uttar Pradesh 201314, India. ${ }^{5}$ Present Address: Center for Optics, Photonics and Lasers, Laval University, Quebec City, QC G1V 0A6, Canada. 
depends on its oxidation state, with the trivalent form of arsenic being more toxic than the pentavalent and organic arsenic. Unfortunately, there is no known cure for arsenic poisoning and therefore providing arsenic-free drinking water is the only way to avoid the adverse health effects of arsenic.

In the last decades, researchers have developed several techniques to remove arsenic from the water using a variety of adsorbents [7-14]. Arai et al. [7] studied As (III) and As (V) adsorption at the aluminum oxide-water interface and highlighted the importance of $\mathrm{pH}$ on the mechanisms of As (V) and As (III) adsorption. Lenoble and his coworkers observed arsenic adsorption onto pillared clays and iron oxides and found that amorphous iron hydroxide was an effective adsorbent for both As (V) and As (III) [8]. GençFuhrman et al. [9] developed a sand-red mud column to remove As (V) from water while As (III) removal from the water was successfully achieved by Kundu et al. using iron oxide-coated cement $[10,11]$. The point of zero charges (PZC) of iron oxide coated cement is higher than that of pure iron oxide, which was the proposed reason behind its higher As (III) removal capacity [10, 11]. Composite of metal oxides with graphene oxide has also been used to remove arsenic from drinking water since oxides are known to have a high affinity for heavy metals $[12,13]$. Despite the plethora of materials and techniques available for the removal of arsenic from water, the scientific community is still in pursuit of fast, facile and more costeffective solutions, which can provide arsenic-free water to the less privileged countries.

Along with the arsenic, contamination of drinking water with the pathogens is another challenging problem as the pathogens cause many waterborne diseases such as diarrhea, which is a leading cause of illness and death. Escherichia coli (E. coli) bacteria is one such pathogen that causes mild to severe bloody diarrhea $[15,16]$. Staphylococcus aureus (S. aureus) is another pathogen, which is responsible for a variety of skin abscesses and enterocolitis [17]. Significant health benefits from the use of basic household water filters such as ceramic water filters and biosand filters have been reported in the literature [18-21]. These filters are effective to remove heavy metals as well as biological contamination. Even so, we need a good quality point of use water filters that can remove both heavy metals such as arsenic and biological contamination to provide safe drinking water in less developed countries.

Safe disposal of red mud (RM) is another challenging environmental issue. The red mud is a solid waste produced in the process of aluminium production from bauxite following the Bayer process. Presently, it is stored or dumped in the ocean or land near alumina refineries. However, its high alkalinity is a potential pollution threat to water, land, and air $[22,23]$. Therefore, beneficial uses of this hazardous material are desirable. There are many reports in the literature on the possible application of red mud in environment management and water treatment after proper neutralization [24-27]. Mineralogically, red mud mainly consists of oxides of iron and aluminum along with traces of other oxides such as titanium dioxide, silicon oxide, sodium oxide, calcium oxide $[28,29]$. As discussed above, the removal of $A s(V)$ from water usually relies on adsorption with aluminum and iron oxides, thus $A s(V)$ is expected to have a high affinity of red mud, and is used in recent times for arsenic removal from drinking water. However, in order to utilize the red mud for arsenic adsorption activation of red mud is mandatory. Several activation processes such as acid activation, thermal activation, bauxsol activations, etc. are employed in order to utilize red mud for arsenic removal from water [22, 26, 28].

In this present study, a simple mechanical process was exploited to activate the as-received red mud by producing its nanoparticles. The effectiveness of the as-prepared red mud nanoparticles as an arsenic adsorbent was investigated and the effect of milling time and grain size as a function of adsorption capability were examined. An indepth kinetic and transport study was further carried out in order to understand the adsorption kinetics. Finally, red mud nanoparticles were utilized to fabricate a column filter. The competence of the filter as a versatile biochemical filtration assembly was studied and successful amalgamate removal of arsenic, E. coli and S. aureus from drinking water was achieved.

\section{Materials and methods}

\subsection{Materials}

The red mud (RM) used in the study was collected from National Aluminium Company Limited (NALCO), India. The $\mathrm{RM}$ was first dried at $100^{\circ} \mathrm{C}$ for $1 \mathrm{~h}$ and then grinded for $1 \mathrm{~h}$ using an electrical mortar and pestle (IKON Instruments, India) to make a fine powder (grain size 180-200 nm).

\subsection{Analytical methods}

The chemical composition of RM was analyzed using a PANalytical Epsilon 5 X-ray Fluorescence (XRF) and the morphology was investigated using FEl Inspect F50 Scanning Electron Microscope (SEM). The particle size was measured using a particle size analyzer (Malvern Panalytical, USA). The BET analysis was carried out to measure the specific surface area of RM-0 and RM-10 with a Quantachrome Autosorb-1 BET surface area analyzer at $77 \mathrm{~K}$. As (V) concentrations were determined through spectroscopic analysis using the molybdenum blue method 
$[30,31]$ and a UV-VIS-NIR spectrophotometer (UV3700, Shimadzu, Japan).

\subsection{Preparation of nanoparticles of red mud}

Red mud nanoparticles were prepared by mechanically processing RM in a ball mill. The size of the red mud nanoparticles was controlled by varying milling time from 5 to $10 \mathrm{~h}$. Ball milling of the RM was done at $150 \mathrm{rpm}$ in a Retsch PM 200 mill (India) with a weight ratio of 8:1 between the ball ( $5 \mathrm{~mm}$, stainless steel) and RM. The prepared samples are assigned names as RM- $0, \mathrm{RM}-5, \mathrm{RM}-8$, and RM-10 respectively for $0 h, 5 h, 8 h$, and $10 \mathrm{~h}$ ball milling.

\subsection{Arsenate adsorption experiments}

All chemicals were of analytical grade and used without further purification. All glasswares were cleaned using a diluted ( $5 \mathrm{M}) \mathrm{H}_{2} \mathrm{SO}_{4}$ solution for half an hour and washed three times with deionized water. As ( $\mathrm{V}$ ) stock solution was prepared using $\mathrm{Na}_{2} \mathrm{HAsO}_{4} \cdot 7 \mathrm{H}_{2} \mathrm{O}$ as an arsenic source. A $100 \mathrm{mg} / \mathrm{L}$ or $100 \mathrm{ppm}$ of As (V) stock solution was prepared by dissolving $0.42 \mathrm{~g} \mathrm{Na}_{2} \mathrm{HAsO}_{4} \cdot 7 \mathrm{H}_{2} \mathrm{O}$ in $1 \mathrm{~L}$ of distilled water. This stock solution was used to prepare test solutions of different As $(\mathrm{V})$ concentrations in DI water $(\mathrm{pH}$ 7.1).

Adsorption studies were carried out in batch experiments at $30^{\circ} \mathrm{C}$ in an orbital shaker at $250 \mathrm{rpm}$. Experiments were carried out for all the RM nanoparticles to investigate the effect of contact time, initial As (V) concentration and size of the particles on As ( $V$ ) adsorption capacity. All experiments were carried using a $100 \mathrm{~mL}$ As (V) solution (at different concentrations) with $500 \mathrm{mg} \mathrm{RM}$. At a predetermined time, the reaction contents were centrifuged for $5 \mathrm{~min}$ at $5000 \mathrm{rpm}$ and the supernatant was analyzed for As (V) in solution. The amount of As (V) adsorbed on the $\mathrm{RM}$ was calculated from the amount of $A s(\mathrm{~V})$ removed from the water.

\subsection{Water column filter preparation}

Filter columns were made using $5 \mathrm{~mL}$ syringes having a $0.45 \mu \mathrm{m}$ membrane filter at their base; each column was packed with $0.6 \mathrm{~g}$ of RM nanoparticles. The depth and diameter of the RM bed were 7 and $13 \mathrm{~mm}$, respectively. As prepared columns were used to investigate the filtration capacity of red mud nanoparticles in removing As (V), E. coli and S. aureus from the water. Hydraulic conductivity of the different RM filter beds was also determined by the falling head method [32].

\subsection{E. coli and S. aureus removal study}

E. coli MG1655 (wild-type) and Staphylococcus aureus (UAMS-1) strains were grown in Luria-Bertani (LB) medium containing casein enzymic hydrolysate $(10 \mathrm{~g} / \mathrm{L})$, yeast extract $(5 \mathrm{~g} / \mathrm{L})$, sodium extract $(5 \mathrm{~g} / \mathrm{L})$ and incubated overnight at $37^{\circ} \mathrm{C}$ under aerobic condition. For making solid medium plates, $1.5 \%$ agar was added to the LB medium. All reagents were purchased from $\mathrm{Hi}$-media Laboratory Pvt. Ltd (India).

The bacterial removal performance of filter columns packed with RM samples was determined using the following approach. Overnight grown E. coli and S. aureus cultures in LB medium were diluted tenfold in $1 \times$ phosphate buffer saline (PBS) and $2 \mathrm{~mL}$ of that culture suspension was poured over the columns and kept for $2 \mathrm{~h}$ at room temperature. Effluent from the filter column was serially diluted in $1 \times$ PBS and $100 \mu \mathrm{L}$ of it was spread on LB agar plates in triplicate. Plates were incubated overnight at $37^{\circ} \mathrm{C}$ followed by counting of the colony-forming units (CFUs). The experiments were repeated three times independently.

\section{Results and discussion}

\subsection{The chemical composition of RM}

The chemical and mineralogical composition of RM as obtained from the XRF analysis is listed in Table 1, which shows that RM contains mostly iron oxides and aluminum oxides (about $70 \%$ of the total mass). The other constituents present in RM are the oxides of silicon, sodium, titanium, calcium, magnesium, and manganese.

\subsection{Morphology of RM}

SEM images of RM nanoparticles are shown in Fig. 1. The size of the unactivated RM (RM-0) sample was about 180-200 nm (Fig. 1a), and it decreased to $35-50 \mathrm{~nm}$ (Fig. 1b), 25-35 nm (Fig. 1c), 15-25 nm (Fig. 1d) for ball milling time of 5, 8 and $10 \mathrm{~h}$, respectively. Thus, it is evident that the particle size reduces with the increase in ball milling time. In addition to this, there is a uniformity in the

Table 1 Chemical and mineralogical composition of red mud used in this study

\begin{tabular}{lc}
\hline Constituent & $\%(w / w)$ \\
\hline $\mathrm{Fe}_{2} \mathrm{O}_{3}$ & 54.8 \\
$\mathrm{Al}_{2} \mathrm{O}_{3}$ & 14.8 \\
$\mathrm{SiO}_{2}$ & 6.4 \\
$\mathrm{Na}_{2} \mathrm{O}$ & 4.8 \\
$\mathrm{TiO}_{2}$ & 3.7 \\
$\mathrm{CaO}$ & 2.5 \\
\hline
\end{tabular}

SN Applied Sciences a SPRINGER NatURE journa 

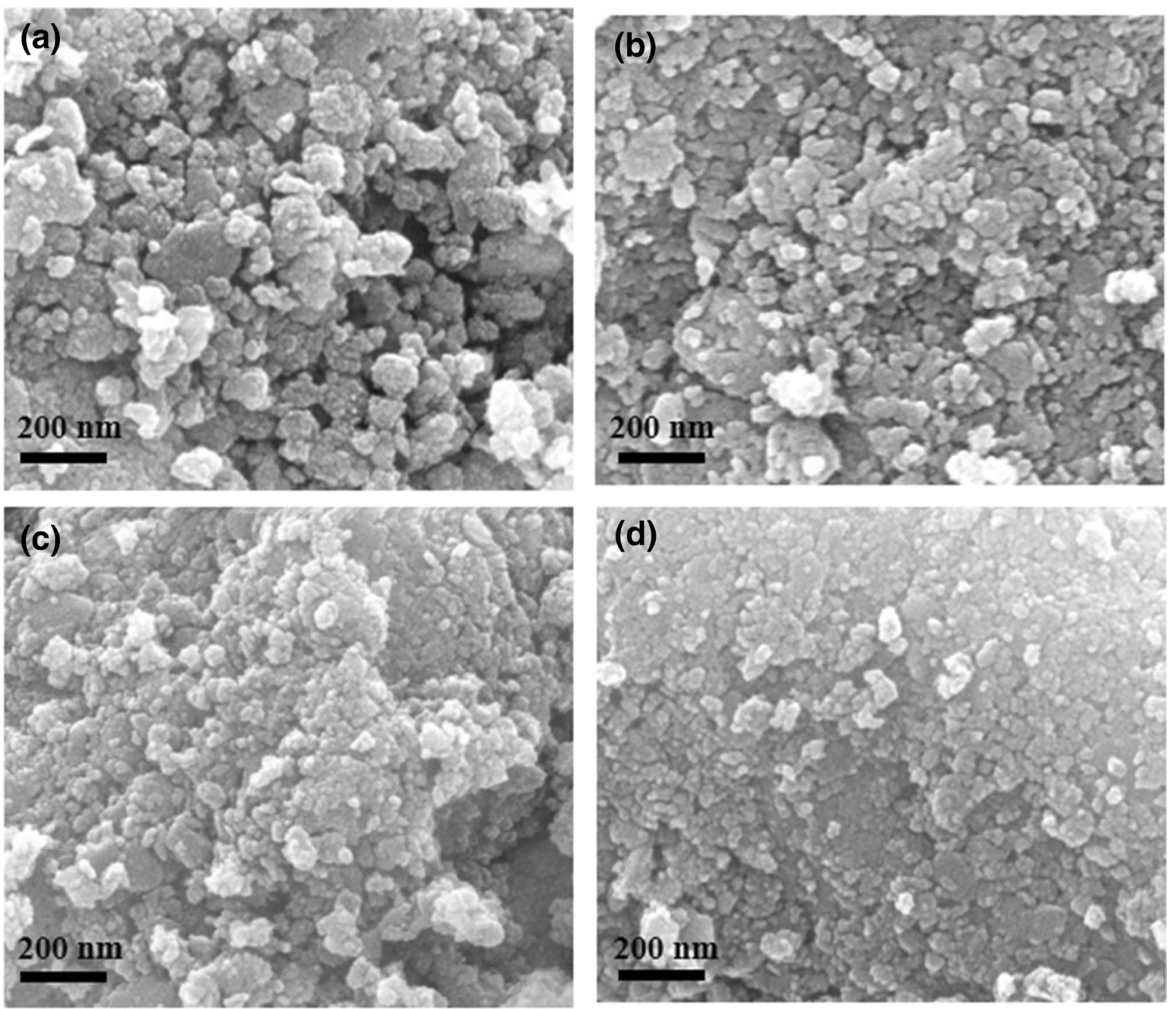

Fig. 1 SEM images of a RM-0, b RM-5, c RM-8 and d RM-10 red mud nanoparticles

particle size distribution and also the particle shape transforms to a more 'spherical like' in nature; these results confirm that uniform nanoparticulate RM can be effectively produced by ball milling.

Particle size analysis a semiquantitative approach, which is widely used to obtain the particle size distribution, has also been carried out. The correlation between particle size as a function of milling time is plotted in a bar diagram and is represented in Fig. 2a. The plot of average particle size distribution as a function of milling time exhibits that the average particle size of the RM-0 particles was $\sim 210 \pm 40 \mathrm{~nm}$ and with milling, there is a continuous decrease in average particle size where for the $10 \mathrm{~h}$ milled sample (RM-10) the average particle size was found to be $\sim 40 \pm 10 \mathrm{~nm}$.
Brunauer-Emmett-Teller (BET) analysis was used to calculate the surface area of RM-0 and RM- 10 samples. Nitrogen adsorption-desorption analysis was carried out and is represented in Fig. 2b. The BET surface area of RM-0 was evaluated as $21.65 \mathrm{~m}^{2} / \mathrm{g}$, whereas, for the ball-milled sample milled for $10 \mathrm{~h}$ there was a significant $\sim 1.6$ times enhancement in the surface area and a surface area of $34.27 \mathrm{~m}^{2} / \mathrm{g}$ was calculated.

\subsection{Arsenate adsorption on RM}

The effect of various parameters such as particle size, initial As (V) concentration and contact time on arsenate adsorption characteristics of RM was investigated. The As (V) adsorbed on the RM was calculated using Eq. (1) as [24]: 

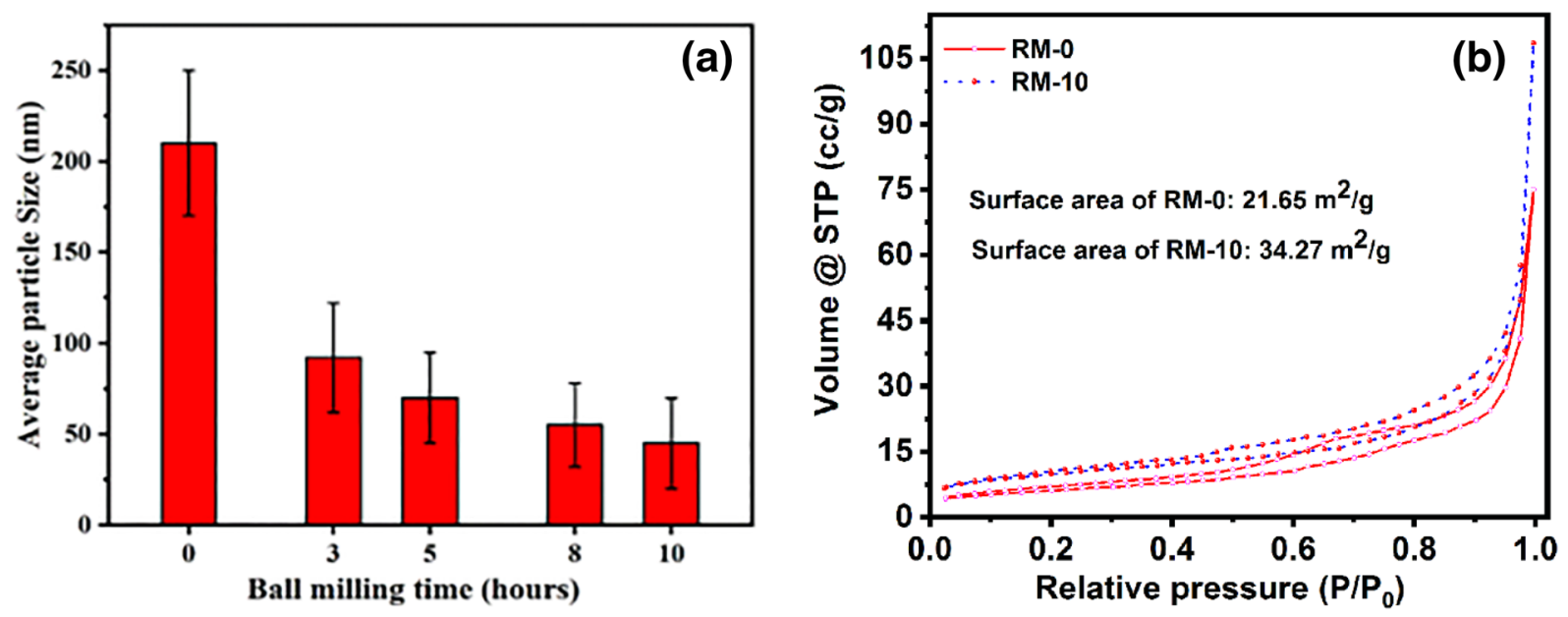

Fig. 2 a Variation of the average particle size of red mud as a function of milling time and $\mathbf{b}$ BET surface area-Nitrogen adsorption-desorption for RM-0 and RM-10

$q=\frac{\left(C_{0}-C_{e}\right) V}{M}$

where $q$ is the amount of As (V) adsorbed in $\mu \mathrm{g} / \mathrm{g}, C_{0}$ and $C_{e}$ are the initial and final concentrations of the $A s(V)$ in water, $\mathrm{V}$ is the volume of $\mathrm{As}(\mathrm{V})$ solution and $\mathrm{M}$ is the mass of adsorbent.

The amount of As (V) adsorbed on raw RM and RM nanoparticles prepared through ball milling for different durations are shown in Fig. 3. These results show that As (V)adsorption increased with the contact time until the equilibrium was achieved around 4-8 h, depending on the conditions. Figure 3a-d reveals that the amount of As (V) adsorbed on RM samples increased when decreasing particle size of $\mathrm{RM}$, which might be because of the increase in the surface area of the RM when reducing the particle size. The large surface area offers a higher number of sites for the As (V) to absorb. The adsorption capacity was enhanced significantly for samples that were ball milled in comparison to raw RM. As (V) adsorption capacity and removal efficiency of different RM samples for different initial concentrations of As (V) solutions are summarized in Table 2.

The kinetic parameters corresponding to As ( $\mathrm{V}$ ) adsorption on the RM-0 and RM-10-water interface were evaluated using pseudo 1 st and pseudo 2 nd order kinetic models with various $A s(V)$ concentrations $(0.1,0.5,1.0$ and $10.0 \mathrm{ppm}$ ) at room temperature.

Lagergren pseudo 1 st order kinetic model $[33,34]$ is represented by Eq. (2) as:

$\log \left(q_{\text {e/expt }}-q_{t}\right)=\log \left(q_{\text {e/fitted }}\right)-\left(k_{1} t / 2.303\right)$ where $k_{1}$ is the rate constant of pseudo 1 st order rate kinetic and $q_{t}, q_{e / \text { expt }}$ and $q_{e / f i t t e d}$ are the adsorption densities of $A s(V)$ at time $t$ and at equilibrium (experimental and fitted respectively). For all the concentrations $k_{1}$ and $q_{e / f i t t e d}$ are evaluated and are represented in Table 3 . The linear variation of $\log \left(q_{e / \text { expt }}-q_{t}\right)$ with time for RM-0 and RM-10 for initial As (V) concentration of $1 \mathrm{ppm}$ is also shown in Fig. 4. From Table 3 (and also from the graph in Fig. $4 a, b$ ) it is quite evident that the fitting is imperfect and the fitted adsorption density for both the samples is much higher compared to the experimental values (Table 3). Further, to check the suitability of the pseudo-second-order kinetic model, the linear form of the model was employed.

The linear form of pseudo-second-order rate kinetics $[33,34]$ is represented by Eq. (3) as:

$t / q_{t}=1 /\left(k_{2} q_{e / \text { fitted }}^{2}\right)+t / q_{e / \text { fitted }}$

where $k_{2}$ is the pseudo 2 nd order rate constant and $q_{e / f i t t e d}$ is the fitted adsorption density. The variation of $t / q_{t}$ with time for As (V) adsorption for RM-0 and RM-10 for all the concentrations were plotted and the values of the pseudosecond-order rate constants and the fitted adsorption densities were estimated from the slope and intercept of the graph and are tabulated in Table 3. The linear variation and the corresponding fit for RM- 0 and RM- 10 samples at an initial concentration of $1 \mathrm{ppm}$ is also represented in Fig. $5 a$, b. The fitting is much improved as compared to the pseudo 1 st order rate kinetics. The $\mathrm{R}^{2}$ values are much improved and the values of $q_{e / f i t t e d}$ for both the samples are closer to the experimental values indicating the kinetics of As (V) adsorption follows the pseudo 2 nd order rate 

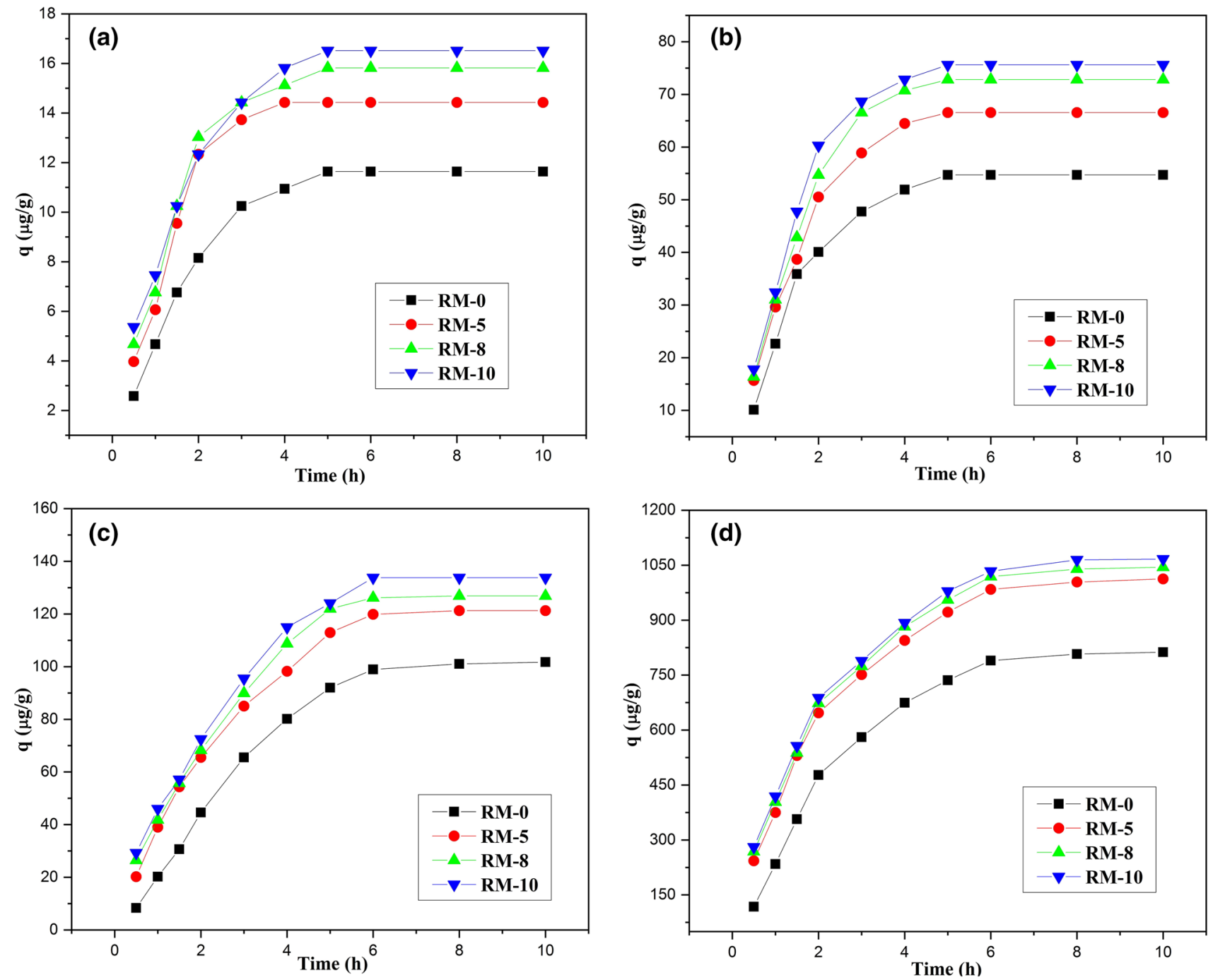

Fig. 3 Effect of the RM milling time on the adsorption of As (V). The initial As (V) concentration was a 100 ppb, b 500 ppb, c 1 ppm and d 10 ppm. See Sect. 2 for details

Table 2 Summary of As (V) adsorption amount and percentage removal for the different RM samples

\begin{tabular}{|c|c|c|c|c|c|c|c|c|}
\hline \multirow{2}{*}{$\begin{array}{l}\text { Initial As conc. } \\
\text { (ppm) }\end{array}$} & \multicolumn{2}{|l|}{$\mathrm{RM}-0$} & \multicolumn{2}{|l|}{ RM-5 } & \multicolumn{2}{|l|}{ RM-8 } & \multicolumn{2}{|l|}{ RM-10 } \\
\hline & $q(\mu g / g)$ & Removal (\%) & $q(\mu g / g)$ & Removal (\%) & $q(\mu g / g)$ & Removal (\%) & $q(\mu g / g)$ & Removal (\%) \\
\hline 0.1 & 11.6 & 58.2 & 14.4 & 72.1 & 15.8 & 79.1 & 16.5 & 82.6 \\
\hline 0.5 & 54.7 & 54.7 & 66.6 & 66.6 & 72.8 & 72.8 & 75.6 & 75.6 \\
\hline 1.0 & 101.7 & 50.9 & 121.3 & 60.6 & 126.8 & 63.4 & 133.8 & 66.9 \\
\hline 3.0 & 297.9 & 49.7 & 337.9 & 56.3 & 357.3 & 59.5 & 382.2 & 63.7 \\
\hline 5.0 & 459.9 & 45.9 & 538.6 & 53.9 & 577.9 & 57.8 & 611.7 & 61.2 \\
\hline 8.0 & 660.0 & 41.3 & 774.0 & 48.4 & 842.8 & 52.7 & 922.2 & 57.6 \\
\hline 10 & 812.5 & 40.6 & 1012.5 & 50.6 & 1044.6 & 52.2 & 1066.9 & 53.3 \\
\hline
\end{tabular}


Table 3 Kinetic model parameters for the adsorption of As (V) onto the RM-0 and RM-10 red mud nanoparticles

\begin{tabular}{|c|c|c|c|c|c|c|c|c|}
\hline \multirow{3}{*}{$\begin{array}{l}\text { As }(V) \text { con- } \\
\text { centration } \\
(p p m)\end{array}$} & \multirow[t]{3}{*}{ Sample } & \multicolumn{7}{|c|}{ Kinetic parameters } \\
\hline & & \multirow[t]{2}{*}{$q_{\text {e/expt }}(\mu \mathrm{g} / \mathrm{g})$} & \multicolumn{3}{|c|}{ Pseudo 1st order } & \multicolumn{3}{|c|}{ Pseudo 2nd order } \\
\hline & & & $\overline{q_{e / f i t t e d}(\mu \mathrm{g} / \mathrm{g})}$ & $K_{1}(1 / h)$ & $\mathrm{R}^{2}$ & $\overline{q_{e / f i t t e d}}(\mu \mathrm{g} / \mathrm{g})$ & $k_{2}(\mathrm{~g} / \mu \mathrm{gh})$ & $\mathrm{R}^{2}$ \\
\hline \multirow[t]{2}{*}{0.1} & RM-0 & 11.63 & 14.45 & 0.757 & 0.97 & 14.18 & 0.0438 & 0.98 \\
\hline & RM-10 & 16.51 & 19.27 & 0.791 & 0.97 & 19.02 & 0.0461 & 0.99 \\
\hline \multirow[t]{2}{*}{0.5} & RM-0 & 51.91 & 66.95 & 0.781 & 0.98 & 67.02 & 0.0208 & 0.98 \\
\hline & RM-10 & 75.60 & 97.37 & 0.885 & 0.97 & 89.28 & 0.0085 & 0.98 \\
\hline \multirow[t]{2}{*}{1.0} & RM-0 & 101.00 & 178.53 & 0.640 & 0.93 & 145.56 & 0.0019 & 0.95 \\
\hline & RM-10 & 133.80 & 158.41 & 0.530 & 0.98 & 177.93 & 0.0021 & 0.98 \\
\hline \multirow[t]{2}{*}{10.0} & $\mathrm{RM}-0$ & 812.54 & 1271.57 & 0.647 & 0.96 & 1000.00 & 0.0005 & 0.99 \\
\hline & RM-10 & 1066.00 & 1735.52 & 0.719 & 0.92 & 1301.78 & 0.0004 & 0.99 \\
\hline
\end{tabular}
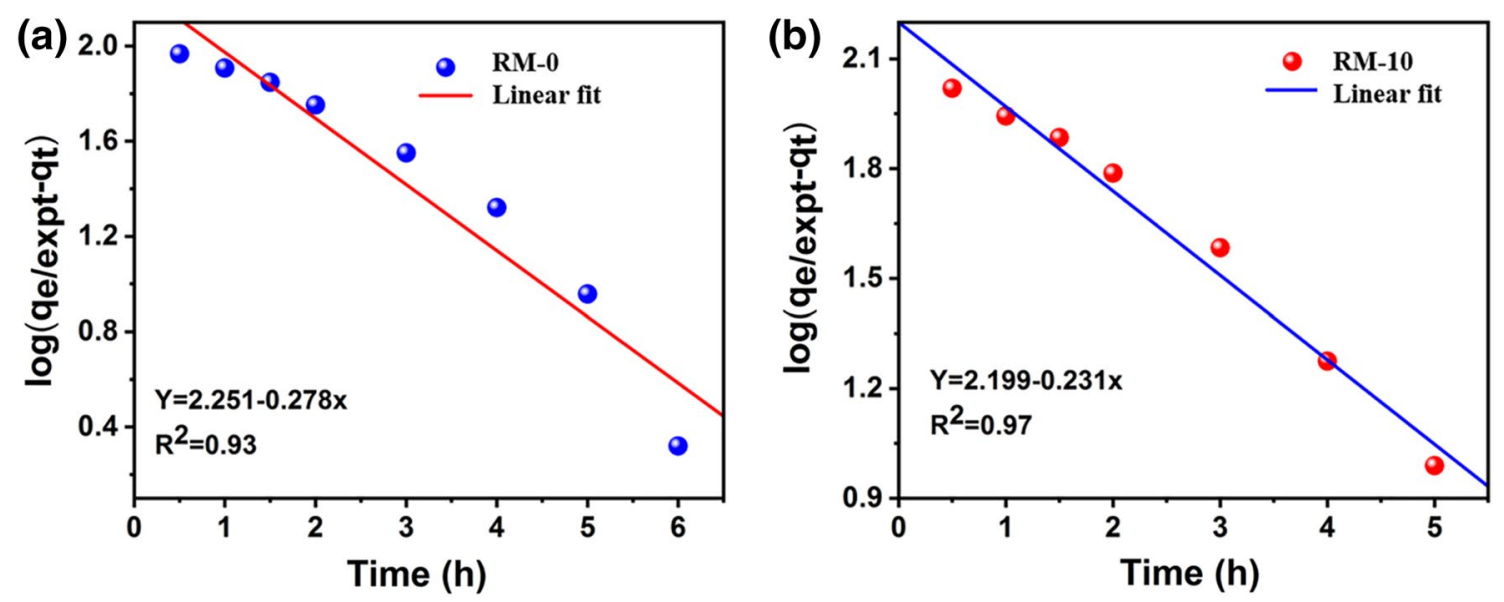

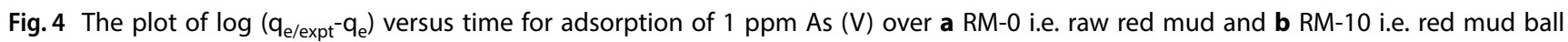
milled for $10 \mathrm{~h}$
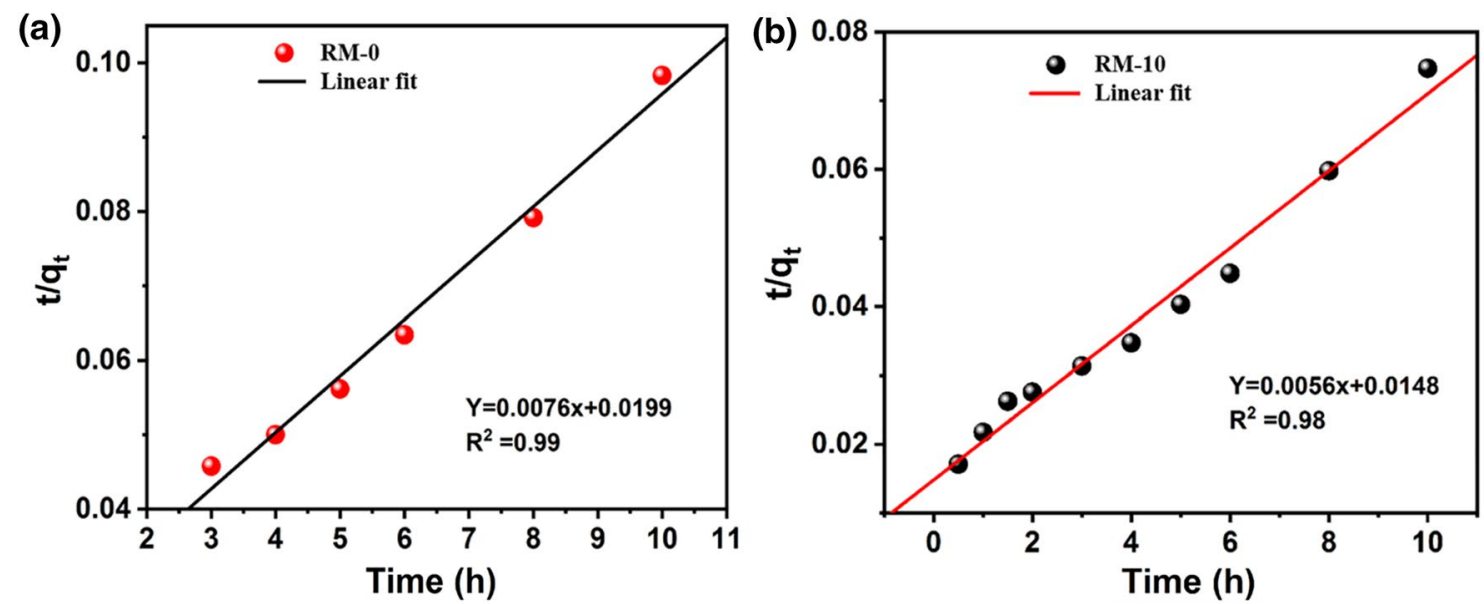

Fig. 5 Variation of t/qt vs. $t$ for 1 ppm As (V) adsorption over a raw red mud (RM-0) and b red mud ball milled for 10 $h(R M-10)$ 
Table 4 Interparticle diffusion model parameters for the adsorption of As (V) onto RM-0 and RM-10 red mud nanoparticles

\begin{tabular}{llcrl}
\hline $\begin{array}{l}\text { Concentration } \\
\text { (ppm) }\end{array}$ & Sample & \multicolumn{3}{c}{ Interparticle diffusion model } \\
\cline { 3 - 5 } & & $K_{1}\left(\mathrm{~g} / \mu \mathrm{gh}^{-1 / 2}\right)$ & \multicolumn{1}{c}{$\mathrm{c}$} & $\mathrm{R}^{2}$ \\
\hline 0.1 & $\mathrm{RM}-0$ & 6.066 & -1.083 & 0.96 \\
& $\mathrm{RM}-10$ & 7.619 & 0.510 & 0.96 \\
0.5 & $\mathrm{RM}-0$ & 28.644 & -4.625 & 0.93 \\
& $\mathrm{RM}-10$ & 38.475 & -3.082 & 0.92 \\
1.0 & $\mathrm{RM}-0$ & 49.230 & -25.126 & 0.97 \\
& $\mathrm{RM}-10$ & 62.812 & -16.068 & 0.97 \\
10.0 & $\mathrm{RM}-0$ & 298.562 & -1.259 & 0.90 \\
& $\mathrm{RM}-10$ & 435.779 & 9.5231 & 0.96 \\
\hline
\end{tabular}

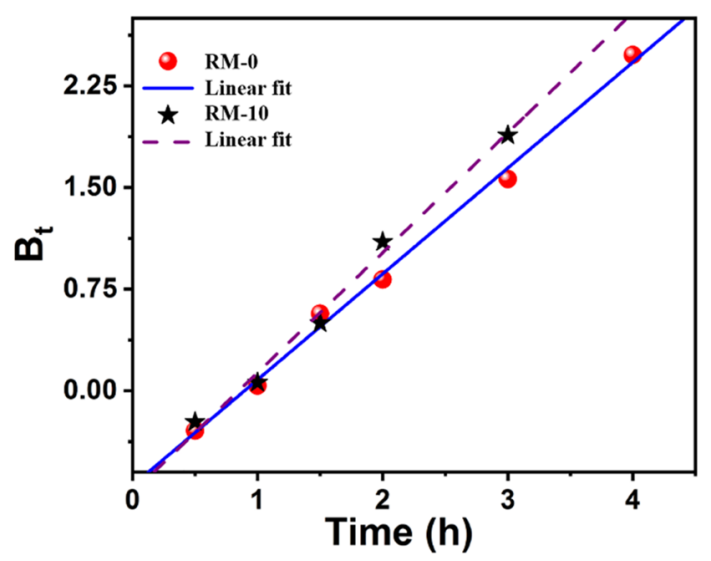

Fig. 6 Variation of $B_{t}$ vs. $t$ for adsorption of 0.5 ppm As (V) over RM-0 and RM-10 red mud nanoparticles

kinetics. It is also noteworthy to mention that similar kind of kinetic models for $\mathrm{As}(\mathrm{V})$ adsorption is proposed by many researchers $[35,36]$ and the calculated pseudo 2 nd order rate constant $\left(k_{2}\right)$ matches nicely with the literature $[37,38]$.

Interparticle diffusion and Boyd kinetic models were further incorporated to investigate the transport mechanism of the adsorption process. The interparticle diffusion model $[34,39]$ is represented by Eq. (4) as:

$q_{t}=K_{1} t^{1 / 2}+c$

where $K_{1}$ is the interparticle diffusion rate constant and c is another constant. The variations of $q_{t}$ with $t^{1 / 2}$ at all As (V) concentrations were plotted and further fitted linearly. The values of $k_{1}$ and $c$ were calculated from the slope and intercept of the linearly fitted data and are represented in Table 4. As the fitted line did not pass through the origin, it indicates the non-acceptability of interparticle diffusion as the rate-limiting process of As (V) adsorption [34]. The Boyd kinetic model [40] was examined by monitoring the variation of Boyd number $\left(B_{t}\right)$ with time. The Boyd number was calculated by Eq. (5) as:

$B_{t}=-0.4977-\ln (1-F)$

Where, $\quad F=q_{t} / q_{e}$

Boyd plots were plotted for RM-0 and RM-10 samples at different As (V) concentration. The linear fitting was further employed. The linear fitted curves of the Boyd model plot for RM- 0 and RM- 10 samples at an initial As $(V)$ concentration of $0.5 \mathrm{ppm}$ is represented in Fig. 6 . The fitted linear curves do not pass through the origin and indicate the external mass transport governs the rate-controlling process for the As (V) adsorption onto RM-0 and RM-10 samples. Din et al. [41] observed and reported a similar transport model for As (V) adsorption on binary iron and silicon oxide.
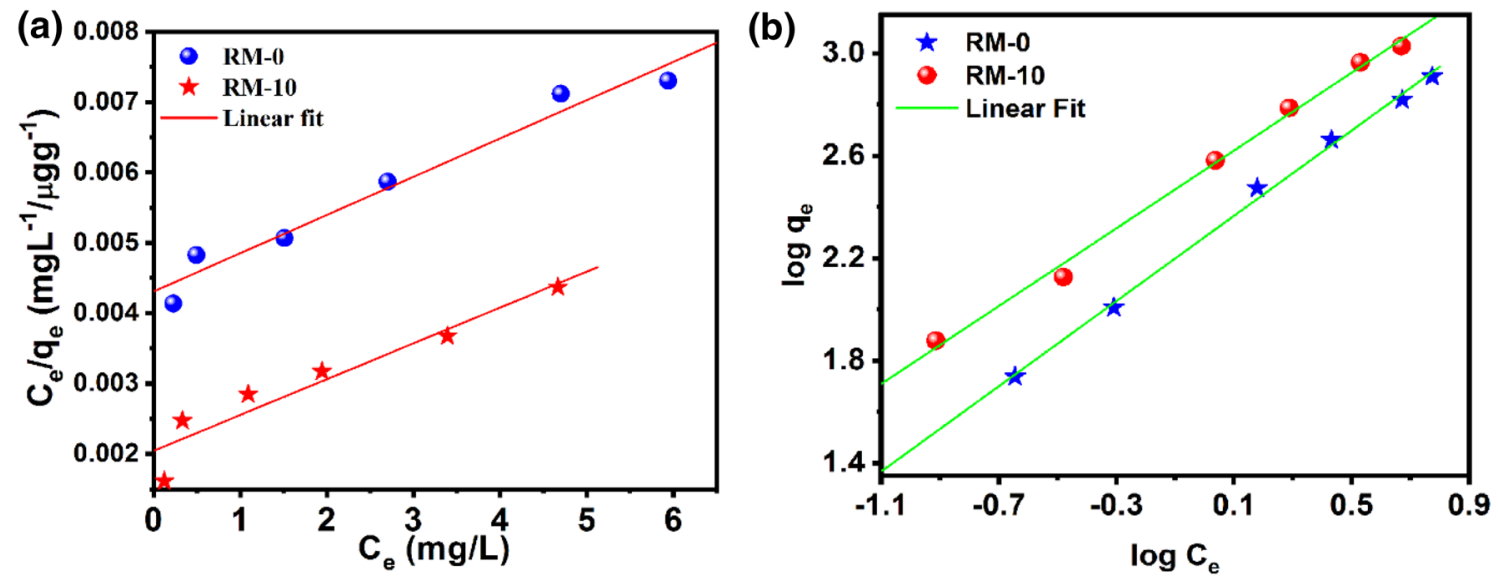

Fig. 7 a Langmuir isotherm plots, b Freundlich adsorption plots for As (V) adsorption on RM-0 and RM-10 red mud nanoparticles 
The adsorption isotherms were further plotted and are represented in Fig. 7. The adsorption isotherm was at first evaluated by the Langmuir model [42] as Eq. (7).

$\frac{C_{e}}{q_{e}}=\frac{1}{Q_{0} b}+\frac{C_{e}}{Q_{0}}$

Here $b$ is the adsorption constant, $Q_{0}$ is the adsorption capacity, and $C_{e}$ is the equilibrium concentration. Linearized isotherms for the Langmuir model are depicted in Fig. 7a. The $\mathrm{R}^{2}$ values for the RM-0 and RM-10 samples were calculated as 0.97 and 0.98 , respectively. adsorption capacity is calculated to be $1.84 \mathrm{mg} / \mathrm{g}$ and $1.96 \mathrm{mg} / \mathrm{g}$ respectively for RM-0 and RM-10 suggesting that the red mud nanoparticles show better adsorption efficacy than raw red mud.

The Freundlich isotherm describing adsorption onto a heterogeneous surface was also evaluated and is represented by Eq. (8) and the model is depicted in Fig. 7b.

The Freundlich isotherm is commonly presented as:

$q_{e}=K_{F} C_{e}^{1 / n}$

where $K_{F}$ and $1 / n$ are the Freundlich constants related to the adsorption capacity and adsorption intensity.

The adsorption capacity is also calculated from the Freundlich adsorption isotherm and evaluated as $2.28 \mathrm{mg} / \mathrm{g}$ and $2.54 \mathrm{mg} / \mathrm{g}$ respectively for RM- 0 and RM-10. The $\mathrm{R}^{2}$ values for both the samples were found to be 0.99 indicating the applicability of the isotherm model. The values of $1 / n$ for RM- 0 and RM-10 were calculated to be 0.76 and 0.83 respectively. The high values of $1 / n$ indicated a higher adsorption ability of the As (V) specimen by the RM adsorbents.

Our results show greater capacity than most values reported in the literature. The higher adsorption capacity was achieved for red mud activated using acid, making bauxsol and through coating with other materials [9, 24]. Genc-Fuhrman et al. observed an As (V) adsorption capacity of $2.14 \mathrm{mg} / \mathrm{g}$ using $5 \mathrm{~g} / \mathrm{L}$ dosage activated bauxsol coated sand [9]. Sahu et al. reported a higher adsorption capacity of As (V) onto activated carbon modified with iron oxide nanoparticles [14]. Our approach of making an adsorbent containing nanoparticles derived from red mud is simpler and cost-effective.

\subsection{Filtration study using column filter}

Two filter columns were packed, one with RM-0 and the other with RM-10. Both columns were tested for the removal of As (V), E. coli and S. aureus. The hydraulic
Table 5 Performance of RM column filters: hydraulic conductivity and $\mathrm{As}(\mathrm{V})$ removal (for $1 \mathrm{ppm}$ As in the influent)

\begin{tabular}{|c|c|c|}
\hline Column material & $\begin{array}{l}\text { Hydraulic conductivity } \\
(\mathrm{mm} / \mathrm{h})\end{array}$ & As removal (\%) \\
\hline Without RM ${ }^{\mathrm{a}}$ & 490 & 18.8 \\
\hline RM-0 & 3.2 & 54.4 \\
\hline RM-10 & 8 & 61.3 \\
\hline
\end{tabular}

${ }^{\mathrm{a}} 0.45 \mu \mathrm{m}$ membrane filter only

Table 6 E. coli and S. aureus removal efficacy of column filter packed with raw red mud (RM-0) and $10 \mathrm{~h}$ ball milled red mud (RM10)

\begin{tabular}{llll}
\hline Bacteria & Influent $\left(\mathrm{CFU} / \mathrm{mL}^{-1}\right)$ & $\begin{array}{l}\text { Effluent RM-0 } \\
\text { column } \\
\left(\mathrm{CFU} \mathrm{mL} \mathrm{mL}^{-1}\right)\end{array}$ & $\begin{array}{l}\text { Effluent } \\
\mathrm{RM}-10 \\
\text { column } \\
\left(\mathrm{CFU} \mathrm{mL} \mathrm{mL}^{-1}\right)\end{array}$ \\
\hline E. coli & $1.9 \times 10^{8}$ & $10^{2}$ & $<10$ \\
S. aureus & $3.6 \times 10^{8}$ & $8 \times 10^{2}$ & $10^{2}$ \\
\hline
\end{tabular}

conductivity of the filter packed with RM-10 was found to be about 2.5 times higher than that of the filter packed with RM-0 (Table 5), possibly because of the increase in relative surface area (surface to volume ratio) on reducing the particle size. As expected, As (V) removal by the modified RM filters was found to be higher than the raw RM based filter (see Table 5). This suggests promising possibilities for the incorporation of ball-milled RM in water filtration.

Quantification of E. coli and S. aureus removal in the filters revealed that both indicator organisms were well removed by the modified RM filter. Greater than seven log-reductions of $E$. coli and about six log-reductions of S. aureus was observed (Table 6). The differences between the removal of E. coli and $S$. aureus could be due to the smaller size of $S$. aureus compared with E. coli. Removal in the milled RM filter was one to over two log-reductions better than in the filter packed with raw RM. The smaller particle size of the milled RM resulted in a bed with reduced interstitial pores and thus an enhanced size exclusion filtration can be correlated with the boosted performance of the ball-milled filtration assembly.

\section{Conclusions}

Excellent water filtration capacity was observed in red mud nanoparticles, prepared by ball milling. Red mud nanoparticles were found to be an effective adsorbent for the removal of As $(\mathrm{V})$ and indicator organisms for pathogens from water. Ball milled RM was much more effective for the 
removal of $A s(V)$ than raw red mud. The $A s(V)$ removal from stained water containing $0.1 \mathrm{mg} / \mathrm{L}$ As $(\mathrm{V})$ increases to $82.6 \%$ from $58.2 \%$ on the reduction of particles' size from 200 to $20 \mathrm{~nm}$. Red mud sample milled for $10 \mathrm{~h}$ exhibited improved As (V) adsorption capability and the adsorption kinetics was found to follow pseudo-second-order rate kinetics and was governed by external mass transport. The Freundlich adsorption isotherm exhibited the adsorption capacities of $2.28 \mathrm{mg} / \mathrm{g}$ and $2.28 \mathrm{mg} / \mathrm{g}$ respectively for $20 \mathrm{~nm}$ and $200 \mathrm{~nm}$ nanoparticles. The column filter packed with $20 \mathrm{~nm}$ red mud nanoparticles executed excellent performance to remove both As (V) and pathogens. Greater than seven log-reductions of $E$. coli and about six log-reductions of $S$. aureus was observed in column filter packed with $20 \mathrm{~nm}$ red mud nanoparticles. Overall, the findings of this study show that red mud nanoparticles have excellent potential for use in filters to remove As (V) and microbial contaminants from contaminated water.

Acknowledgments We are grateful to Shiv Nadar University for providing financial assistance for this project. We thank Arka Dey and Partha Pratim Ray of Jadavpur University for the SEM analysis of the samples. Gourav Bhattacharya acknowledges the Commonwealth Split-site Scholarship, from the Commonwealth Scholarship Commission in the UK. We thank Prof. James McLaughlin of University of Ulster for useful discussion on referees comments and helping us in surface area analysis.

\section{Compliance with ethical standards}

Conflict of interest The authors declare that they have no conflict of interest.

\section{References}

1. Andreae MO (1977) Determination of arsenic species in natural waters. Anal Chem 49:820

2. Smedley P, Kinniburgh DG (2013) Arsenic in groundwater and the environment. In: Selinus O (ed) Essentials of medical geology. Springer, Dordrecht, pp 279-310

3. Shrivastava A, Ghosh D, Dash A, Bose S (2015) Arsenic contamination in soil and sediment in India: sources, effects, and remediation. Curr Pollut Rep 1:35

4. Jain C, Ali I (2000) Arsenic: occurrence, toxicity and speciation techniques. Water Res 34:4304

5. Astolfi E, Maccagno A, García Fernández J, Vaccaro R, Stimola $R$ (1981) Relation between arsenic in drinking water and skin cancer. Biol Trace Elem Res 3:133

6. Cheng PS, Weng SF, Chiang CH, Lai FJ (2016) Relationship between arsenic-containing drinking water and skin cancers in the arseniasis endemic areas in Taiwan. J Dermatol 43:181

7. Arai Y, Elzinga EJ, Sparks DL (2001) X-ray absorption spectroscopic investigation of arsenite and arsenate adsorption at the aluminum oxide-water interface. J Colloid Interface Sci 235:80

8. Lenoble V, Bouras O, Deluchat V, Serpaud B, Bollinger JC (2002) Arsenic adsorption onto pillared clays and iron oxides. J Colloid Interface Sci 255:52
9. Genç-Fuhrman H, Bregnhøj H, McConchie D (2005) Arsenate removal from water using sand-red mud columns. Water Res 39:2944

10. Kundu S, Gupta A (2007) Adsorption characteristics of As (III) from aqueous solution on iron oxide coated cement (IOCC). J Hazard Mater 142:97

11. Kundu S, Gupta A (2007) As (III) removal from aqueous medium in fixed bed using iron oxide-coated cement (IOCC): experimental and modeling studies. Chem Eng Journal 129:123

12. Zhang K, Dwivedi V, Chi C, Wu J (2010) Graphene oxide/ferric hydroxide composites for efficient arsenate removal from drinking water. J Hazard Mater 182:162

13. Li L, Zhou G, Weng Z, Shan X-Y, Li F, Cheng H-M (2014) Monolithic Fe2O3/graphene hybrid for highly efficient lithium storage and arsenic removal. Carbon 67:500

14. Sahu UK, Sahu S, Mahapatra SS, Patel RK (2017) Cigarette soot activated carbon modified with $\mathrm{Fe}_{3} \mathrm{O}_{4}$ nanoparticles as an effective adsorbent for $\mathrm{As}(\mathrm{III})$ and $\mathrm{As}(\mathrm{V})$ : material preparation, characterization and adsorption mechanism study. J Mol Liq 243:395

15. Bruneau A, Rodrigue H, Ismäel J, Dion R, Allard R (2004) Outbreak of E. coli O157: $\mathrm{H} 7$ associated with bathing at a public beach in the Montreal-Centre region, Canada Communicable Disease Report 30:133

16. Heijnen L, Medema G (2006) Quantitative detection of E. coli, E. coli $\mathrm{O} 157$ and other shiga toxin producing $E$. coli in water samples using a culture method combined with real-time PCR. J Water Health 4:487

17. LeChevallier MW, Seidler RJ (1980) Staphylococcus aureus in rural drinking water. Appl Environ Microbiol 30:739

18. Ahammed MM, Davra K (2011) Performance evaluation of biosand filter modified with iron oxide-coated sand for household treatment of drinking water. Desalination 276:287

19. Bradley I, Straub A, Maraccini P, Markazi S, Nguyen TH (2011) Iron oxide amended biosand filters for virus removal. Water Res 45:4501

20. Jenkins MW, Tiwari SK, Darby J (2011) Bacterial, viral and turbidity removal by intermittent slow sand filtration for household use in developing countries: experimental investigation and modeling. Water Res 45:6227

21. Young-Rojanschi C, Madramootoo C (2014) Intermittent versus continuous operation of biosand filters. Water Res 49:1

22. Bhatnagar A, Vilar VJ, Botelho CM, Boaventura RA (2011) A review of the use of red mud as adsorbent for the removal of toxic pollutants from water and wastewater. Environ Technol 32:231

23. Liu Y, Lin C, Wu Y (2007) Characterization of red mud derived from a combined Bayer Process and bauxite calcination method. J Hazard Mater 146:255

24. Genç H, Tjell JC, McConchie D, Schuiling O (2003) Adsorption of arsenate from water using neutralized red mud. J Colloid Interface Sci 264:327

25. Huang W, Wang S, Zhu Z, Li L, Yao X, Rudolph V, Haghseresht F (2008) Phosphate removal from wastewater using red mud. J Hazard Mater 158:35

26. Altundogan HS, Altundogan S, Tumen F, Bildik M (2002) Arsenic adsorption from aqueous solutions by activated red mud. Waste Manag 22:357

27. Liang W, Couperthwaite SJ, Kaur G, Yan C, Johnstone DW, Millar GJ (2014) Effect of strong acids on red mud structural and fluoride adsorption properties. J Colloid Interface Sci 423:158

28. Brunori C, Cremisini C, Massanisso P, Pinto V, Torricelli L (2005) Reuse of a treated red mud bauxite waste: studies on environmental compatibility. J Hazard Mater 117:55

29. Wang S, Ang H, Tade M (2008) Novel applications of red mud as coagulant, adsorbent and catalyst for environmentally benign processes. Chemosphere 72:1621 
30. Lenoble V, Deluchat V, Serpaud B, Bollinger J-C (2003) Arsenite oxidation and arsenate determination by the molybdene blue method. Talanta 61:267

31. Tsang S, Phu F, Baum MM, Poskrebyshev GA (2007) Determination of phosphate/arsenate by a modified molybdenum blue method and reduction of arsenate by $\mathrm{S}_{2} \mathrm{O}_{4}{ }^{2-}$. Talanta 71:1560

32. Li HL, Sun PP, Chen S, Xia YQ, Liu S (2010) A falling-head method for measuring intertidal sediment hydraulic conductivity. Ground Water 48:206

33. Ho YS, McKay G (1999) Pseudo-second order model for sorption processes. Process Biochem 34:451

34. Bhattacharya G, Sas S, Wadhwa S, Mathur A, McLaughlin J, Roy SS (2017) Aloe vera assisted facile green synthesis of reduced graphene oxide for electrochemical and dye removal applications. RSC Adv 7:26680

35. Kocabaş ZÖ, Yürüm Y (2011) Kinetic modeling of arsenic removal from water by ferric ion loaded red mud. Sep Sci Technol 46:2380

36. Akin I, Arslan G, Tor A, Ersoz M, Cengeloglu Y (2012) Arsenic (V) removal from underground water by magnetic nanoparticles synthesized from waste red mud. J Hazard Mater 235:62
37. Hu Z-P, Gao Z-M, Liu X, Yuan Z-Y (2018) High-surface-area activated red mud for efficient removal of methylene blue from wastewater. Adsorpt Sci Technol 36:62

38. Wu C, Huang L, Xue S-G, Huang Y-Y, Hartley W, Cui M-Q, Wong $\mathrm{M}-\mathrm{H}$ (2017) Arsenic sorption by red mud-modified biochar produced from rice straw. Environ Sci Pollut Res 24:18168

39. Weber WJ, Morris JC (1963) Kinetics of adsorption on carbon from solution. J Sanit Eng Div 89:31

40. Zou W, Li K, Bai H, Shi X, Han R (2011) Enhanced cationic dyes removal from aqueous solution by oxalic acid modified rice husk. J Chem Eng Data 56:1882

41. Din SU, Mahmood T, Naeem A, Hamayun M, Shah NS (2019) Detailed kinetics study of arsenate adsorption by a sequentially precipitated binary oxide of iron and silicon. Environ Technol 40:261

42. Namasivayam C, Arasi D (1997) Removal of congo red from wastewater by adsorption onto waste red mud. Chemosphere $34: 401$

Publisher's Note Springer Nature remains neutral with regard to jurisdictional claims in published maps and institutional affiliations. 